\title{
Effect of composition and proteolysis on textural characteristics of Croatian cheese ripen in a lamb skin sack (Sir iz mišine)
}

\author{
Ante Rako', Milna Tudor Kalit²*, Zorica Rako3, \\ Denis Petrović4 ${ }^{4}$ Samir Kalit²
}

\begin{abstract}
'Institute for Adriatic Crops and Karst Reclamation, Put Duilova 11, Split, Croatia 2University of Zagreb, Faculty of Agriculture, Department of Dairy Science, Svetošimunska 25, Zagreb, Croatia ${ }^{3}$ Split-Dalmatia County, Administrative Department of Economy, EU Funds and Agriculture, Domovinskog Rata 2, Split, Croatia

${ }^{4}$ Antuna Stipančića 15, Zagreb, Croatia

*Corresponding author: E-mail: mtudor@agr.hr
\end{abstract}

\section{Abstract}

The objective of this study was to determine the effect of composition and proteolysis on textural characteristics of Croatian cheese in a lamb skin sack (Sir iz mišine) over a ripening period of 30 days. Ten ovine milk cheese batches were manufactured according to the traditional manufacturing procedures. The content of total solids, fat, proteins $(P<0.05)$ and salt $(P<0.01)$ significantly increased during cheese ripening. Results of this research showed that $a_{s 1}$-casein hydrolysed more rapid in comparison to the $\beta$-casein. An extensive and significant $(P<0.05)$ degradation of $a_{s 1}$-casein was accompanied by significant $(P<0.05)$ accumulation of $a_{51}-1$-casein. Although $\beta$-casein degradation occurred in cheese to a moderate degree, these changes were not statistically significant. However, the level of $\gamma$-casein increased significantly $(P<0.01)$ in cheese throughout ripening. Due to the extensive proteolysis, both TCA-SN $(P<0.01)$ and WSN $(P<0.05)$ significantly increased throughout ripening time. Results showed significant decrease $(\mathrm{P}<0.05)$ in hardness, cohesiveness and springiness during cheese ripening along with progress of proteolysis. Weakening effect of caseinolysis predominated over the strengthening effect of moisture loss in the texture development of cheese, which could be attributed to the specific conditions in the animal skin sack during ripening.

\section{Key words: cheese in a lamb skin sack, proteolysis, texture, cheese ripening}

\section{Introduction}

Most of the Croatian autochthonous cheeses belong to a group of semi-hard and hard cheeses produced from raw full fat ewe's milk, which ripen at least 3 weeks. Proteolysis, lipolysis and glycolysis are biochemical processes that occur during cheese ripening by the combined action of rennet enzymes, endogenous milk enzymes and enzymes originated from lactic acid bacteria (added or autochthonous) are responsible for the desirable cheese characteristics, but also for those undesir- 
able (Kalit, 2002; Havranek et al., 2014; Kalit, 2015). This biochemical processes include dynamic changes during which complex organic molecules (milk fat, protein, lactose) are degraded into smaller molecules. Since casein and milk fat are the dominant components of cheese dry matter, biochemical reactions take place exactly on them (Fox et al., 2000). Therefore, the above-mentioned biochemical processes are the cause of all physico-chemical modifications in the cheese (Lukač Havranek et al., 2000; Prieto et al., 2002; McSweeney, 2004). Biochemical processes during ripening of cheese play an important role in a forming of cheese sensory properties, as well as in a nutritional value of cheeses. Texture characteristics of cheese are influenced by the chemical composition of milk, technological processes during cheese production and microclimate conditions during ripening (Lucey et al., 2003). The relationship between the fat content of milk and protein content in the dry matter of cheese is inversely proportional, thus noticeably affecting textural characteristics of cheese (Fenelon and Guinee, 1999; Lteif et al., 2009; SánchezMacías et al., 2010). As casein forms the base of cheese structure in which other compounds are incorporated, proteolysis is considered as the most important process, which contributes to the formation of characteristic cheese texture (Ardö et al., 2017).

Sir iz mišine (cheese in a sack) is Croatian autochthonous hard ewe's milk cheese. It is produced on family farms in central Dalmatia (Šibenik-Knin and Split-Dalmatia county), and is regarded as a regional product and a part of the touristic offer. Its main specificity is ripening in a sack made of a lamb skin. Although, lipolysis is the predominant biochemical process during cheese ripening in an animal skin sack and is responsible for the cheese flavour and aroma, proteolysis is also involved in the formation of the desirable cheese flavour (Hayaloglu et al., 2007; Tudor Kalit, 2014). In comparison to cheeses ripened in a natural rind, cheeses ripened in sack have a uniquely strong and piquant flavour. That is attributed to the extensive biochemical processes resulting from the anaerobic ripening conditions in the animal skin and the possible presence of moulds inside the sack (Bijeljac and Sarić, 2005; Yilmaz et al., 2005; Tudor Kalit et al., 2014). Extensive lipolytic and proteolytic re- actions increase the nutritive value of the cheese due to the high content of free amino acids and free fatty acids and contribute therefore to a better digestibility. In terms of the sensory quality, the optimum ripening time for Sir iz mišine is 45 days (Tudor Kalit et al., 2014), but due to increased demand for this cheese in the local market, the ripening time is very often 30 days.

Sir iz mišine belongs to a group of unique and insufficiently researched autochthonous Croatian cheeses. The knowledge about the effect of physico-chemical composition and proteolysis on textural properties of cheeses that ripen in an animal skin sack is limited. Therefore, the aim of this research was to determine physicochemical, proteolytic and textural changes throughout the ripening period of Sir iz mišine and their correlations.

\section{Materials and methods}

\section{Cheese manufacture procedure}

According to the traditional manufacturing procedures, 10 batches of Sir iz mišine were produced in a small scale dairy plant in the hinterland of $\mathrm{Vr}$ lika village. Sir iz mišine was manufactured from raw full-fat ewe's milk (breed Damatian pramenka). Cheesemaking milk, was collected from evening and morning milking, and was stored in a cooling tank at $4{ }^{\circ} \mathrm{C}$ prior to cheese manufacturing.

The milk processing into Sir iz mišine started with the addition of salt $(1.1 \mathrm{~kg}$ of salt/100 L cheese milk). After that, the milk was heated to $32{ }^{\circ} \mathrm{C}$ and microbial rennet in granules was added according to the manufacturer's procedure (Maxiren). When coagulated (setting time was between 45 and 60 min), the curd was cut by a cheese harp into cubeshaped pieces sized approximately to $3 \times 3 \mathrm{~cm}$. Then the curd was subjected to stirring and cutting (into peas or nuts size) while heating it up to $38-39^{\circ} \mathrm{C}$. The curd grains were cooked for 10-15 min, and afterwards the whey was drained in the distribution table. After removing the whey, the curd was dry-salted with a large-grain sea salt and put into plastic moulds to self-pressure. During the first 2-4 hours, the cheese was turned in the mould twice, and afterwards it was put overnight in the ripening chamber. The next morning, cheeses were cut into four pieces, dry- salted with large-grain sea salt 
and then put into a lamb skin sack. Prior to use, the skin was submerged into whey or hot water. All openings were steadily closed except the neck, through which the cheese was filled. The average weight of the cheese in a sack was, depending on the size of the lamb skin, $20 \mathrm{~kg}$. Cheese was ripened in the lamb skin sack for 30 days at $16-18{ }^{\circ} \mathrm{C}$ and relative air humidity of $65-80 \%$.

\section{Sampling of cheese}

The samples of curd ( 0 day) and cheese at 15 and 30 days of ripening were taken from each batch for physico-chemical, proteolytic and textural analysis. A sterile knife was used to take samples of about $100 \mathrm{~g}$ intended for physico-chemical analysis. The sampling was performed through the neck opening of the sack. Samples (height 90 $\mathrm{mm}$, diameter $17 \mathrm{~mm}$ ) inteded for texture profile analysis were taken from the middle of the whole cheese block using the sterile cork borer. To avoid dehydration, samples were wrapped into a plastic film. Cheese samples were transported into the laboratory using a mobile cooler at a temperature of $4{ }^{\circ} \mathrm{C}$. Approximately $0.5 \mathrm{~cm}$ of the surface section of the cheese samples was discarded and the rest was stored in plastic bags at $-80{ }^{\circ} \mathrm{C}$ until the physico-chemical analysis. Two cylindrical samples (height $25 \mathrm{~mm}$, diameter $17 \mathrm{~mm}$ ) were cut from each original sample using a stretched-wire cutting device. These samples were wrapped into a plastic film, stored at $4{ }^{\circ} \mathrm{C}$ and analysed at texture analyser within the next 24 hours. After each sampling time, the skin sack was again tied up tight and stored in the ripening room.

\section{Compositional analysis of cheese during ripening}

Analyses of cheese curd ( 0 day) and cheese after 15 and 30 days of ripening included: determination of the total solids by the reference method 5534 (ISO 2008), the fat content according to the Van Gulik method 3433 (ISO 2009), the salt content according to Mohr AOAC 935.43 (AOAC 1995) and the $\mathrm{pH}$ value (Mettler Toledo, Seven Multi, according to manufacturer's instructions). The protein content, the water-soluble nitrogen fraction in the total nitrogen (WSN \%TN) and the $12 \%$-trichlo- roacetic acid soluble nitrogen fraction in the total nitrogen (TCA-SN \%TN) were determined by the Kjeldahl method 8968-1 (ISO 2014). The physicochemical analysis and nitrogen fractions of curd and cheese in a sack were conducted at the Reference Laboratory, Faculty of Agriculture, University of Zagreb, Croatia.

\section{Analysis of proteolytic changes of cheese during ripening}

To evaluate the intensity of the primary proteolytic changes during ripening of Sir iz mišine, the gel-electrophoresis method on polyacrylamide gel (urea-PAGE) was used. Cheese was grated and 0.4 $\mathrm{g}$ of cheeses was mixed in a tube with $5 \mathrm{~mL}$ of urea buffer. The contents of the tube were then heated in a water bath for 30 minutes at a temperature of $40^{\circ} \mathrm{C}$ until the cheese had completely dissolved. Afterwards the content was centrifuged at $3600 \mathrm{rpm}$ at $4{ }^{\circ} \mathrm{C}$ for 10 minutes. A separated layer of fat was removed using vacuum pump and $100 \mu \mathrm{L}$ of the supernatant was mixed with $300 \mu \mathrm{L}$ of buffer. $6 \mu \mathrm{L}$ of the prepared sample was applied to the gel well. The gels were scanned using the Gel Doc 2000 (BIO RAD) device, which has specific densitometric values for gel bands using Quantity One, Quantitation Software (BIO RAD). Densitometric values are expressed as a percentage of a particular casein fraction relative to the total amount of urea buffer soluble casein fractions.

\section{Texture profile analysis}

Texture profile analysis (TPA) was performed by a two-bite compression test using the TA Plus Texture Analyser (Lloyd Instruments Ltd., Fareham, England) fitted with a round aluminium compression plate (ST 6/1-50 mm). Prior to testing, cylindrical samples were allowed to reach room temperature $\left(25^{\circ} \mathrm{C}\right)$. To avoid friction, the compression plate was lubricated with mineral oil. The TPA test was conducted using the Nexygen Plus 3 software at $70 \%$ compression with crosshead speed 50 mm/ min and a retention time of $5 \mathrm{~s}$ between first and second compressive cycle. The parameters measured were hardness, cohesiveness and springiness. In the software manual, hardness was defined as the peak force during the first compression cycle. 
Cohesiveness was defined as the ratio of the area under the second compression curve to that of the first compression curve. Springiness was defined as the ratio of the sample height at the start of the second compression cycle and sample height at the start of the first compression cycle.

\section{Statistical analysis}

Statistical procedures were carried out in SPSS (2012; version 21). One way ANOVA and general linear model (GLM) were used to study the significance of physicochemical, proteolytic and textural changes in cheese during ripening. Pairwise comparisons of mean values were performed using the least significant difference (LSD) test. The relationship among variables were analysed by Pearson's coefficient of correlation.

\section{Results and discussion}

\section{Physicochemical composition}

The age related changes in the physicochemical characteristics of cheese in a sack are given in Table 1. The content of total solids, fat and proteins increased significantly $(\mathrm{P}<0.05)$ as a consequence of moisture loss during the cheese ripening. Similar trend towards an increase in the contents of these components in cheese during ripening were reported by Tudor Kalit et al. (2014) and Lešić et. al (2015). At the end of ripening, the content of total solids, fat and proteins were 58.20, 31.28 and $22.18 \mathrm{~g} / 100 \mathrm{~g}$, respectively, which were higher than those reported by Lešić et. al (2015). On the contrary, Tudor Kalit et al. (2014) reported the higher values of total solids, fat and proteins to those reported in this study due to the faster moisture loss especially during the first 15 days of maturation. Since lamb skin bag has a porous structure, it is able to lose moisture (Hayaloglu et al., 2007). Accordingly, results of the previous research showed that the permeability of the natural cheese rind is higher than the permeability of the animal skin. This allows more loss of moisture and due to that, cheese in a natural rind has a higher content of total solids in relation to cheese in a sack at all ripening stages (Tudor Kalit et al., 2014). The presence of greater proteolytic activity (Table 2), in comparison to the results of Tudor Kalit et al. (2014), could be related to the lower moisture loss during ripening of cheese in this research. Cheese moisture contains residual rennet that enhanced breakdown of its protein structure leading to a formation of proteolytic products with different molecular weight (Bansal et al., 2007). Proteolytic products fills porous structure of skin and consequently reduce moisture loss from cheese (Zengin et al., 2016). On the other hand, the part of ionic charged proteolytic residues competed with free water and remained within cheese protein structure (Ong et al., 2017). It is important to emphasize that fat globules within the para-casein network have clogging effect and therefore contributes to water loss reduction (Mateo et al., 2009). The salt content significantly increased $(\mathrm{P}<0.01)$ during the ripening from 1.16 to $1.91 \%$ (Table 1). These results were not consistent with those of Şengül et al. (2014) who reported the higher values of salt (3.66 \%) in a 30-day-old Tulum cheese, Turkish cheese that ripen in an animal skin sack. Although moisture in non-fat substances decreased gradually during cheese ripening, it was not statistically significant (Table 1), which is not in accordance with results obtained by Tudor Kalit et al. (2014).

TABLE 1. Compositional changes during ripening of Sir iz mišine, $n=25$ (means \pm standard error)

\begin{tabular}{|l|l|l|l|l|}
\hline \multirow{2}{*}{ Parameter } & \multicolumn{3}{l|}{ Ripening time (days) } & \multicolumn{3}{l|}{} \\
\cline { 2 - 5 } & 0 & 15 & 30 & Effect \\
\hline Total solids $(\mathrm{g} / 100 \mathrm{~g})$ & $54.90^{\mathrm{a}} \pm 0.83$ & $56.61^{\mathrm{ab}} \pm 0.80$ & $58.20^{\mathrm{b}} \pm 0.81$ & $*$ \\
\hline Milk fat $(\mathrm{g} / 100 \mathrm{~g})$ & $28.75^{\mathrm{a}} \pm 0.65$ & $30.28^{\mathrm{ab}} \pm 0.64$ & $31.28^{\mathrm{b}} \pm 0.65$ & $*$ \\
\hline Proteins $(\mathrm{g} / 100 \mathrm{~g})$ & $20.86^{\mathrm{a}} \pm 0.35$ & $21.54^{\mathrm{a}} \pm 0.35$ & $22.18^{\mathrm{b}} \pm 0.34$ & $*$ \\
\hline MNFS (\%) & $63.31 \pm 0.83$ & $62.20 \pm 0.83$ & $60.77 \pm 0.82$ & NS \\
\hline Salt (\%) & $1.16^{\mathrm{a}} \pm 0.10$ & $1.64^{\mathrm{b}} \pm 0.10$ & $1.91^{\mathrm{b}} \pm 0.11$ & $*$ \\
\hline pH & $5.22^{\mathrm{a}} \pm 0.04$ & $5.04^{\mathrm{b}} \pm 0.03$ & $5.20^{\mathrm{a}} \pm 0.04$ & $*$ \\
\hline
\end{tabular}

Means within a row marked with different letter differ significantly, ${ }^{*} \mathrm{P}<0.05,{ }^{* *} \mathrm{P}<0.01$, NS $=$ non significant,

MNFS = moisture in non-fat substance. 


\section{Proteolysis}

The values for primary and secondary proteolysis products during cheese ripening are shown in Table 2. Primary proteolysis, especially in cheeses in which production high temperatures are not used, involves the initial breakdown of paracasein network by chymosin, and in lesser extent by plasmin, into casein fractions (Sousa et. al., 2001). These proteolytic products with an intermediate and low molecular mass contribute to aroma and texture development in cheese. The results of ANOVA showed that significant $(P<0.05)$ and extensive degradation of $a_{s 1}$-casein was accompanied by significant $(\mathrm{P}<0.05)$ accumulation of $\mathrm{a}_{\mathrm{s} 1}$-l-casein in cheese during ripening. Although there was a moderate degradation of $\beta$-casein during cheese ripening, these changes were not statistically significant. However, level of $y$-casein increased significantly
$(\mathrm{P}<0.01)$ in cheese throughout ripening. Similar results were reported by Pirisi et. al. (2007) for Fiore Sardo as well as by Celik and Tarakci (2017) for Tulum cheese. In this and other studies (Şengül et al., 2014; Celik and Tarakci, 2017), $\mathrm{a}_{\mathrm{s} 1}$-casein hydrolysed more rapidly in comparison to $\beta$-casein. The results of this study indicated that $60.66 \%$ of the $a_{s 1}$-casein and $90.49 \%$ of the $\beta$-casein initially present in cheese were remained intact at the end of ripening period because of higher initial retention of rennet in the curd. Similar results for intact $\beta$-casein (90.14\%), but with higher value for intact $a_{51}$-casein $(84.96 \%)$ were obtained in Tulum cheese (Celik and Tarakci, 2017). Since $a_{s 1}$-casein showed higher susceptibility to rennet action and $\beta$-casein to plasmin action (Farkye and Fox, 1999; Ardö et al., 2017), it is clear that rennet had a dominant proteolytic activity over plasmin during the cheese ripening (Table 2).

TABLE 2. Proteolytic changes during ripening of Sir iz mišine, $n=10$ (means \pm standard error)

\begin{tabular}{|c|c|c|c|c|}
\hline \multirow[t]{2}{*}{ Parameter } & \multicolumn{4}{|c|}{ Ripening time (days) } \\
\hline & 0 & 15 & 30 & Effect \\
\hline $\mathrm{a}_{\mathrm{s} 1}$-casein (\%) & $24.99^{a} \pm 2.76$ & $17.48^{\mathrm{ab}} \pm 2.77$ & $15.16^{b} \pm 2.76$ & * \\
\hline $\mathrm{a}_{\mathrm{s} 1}-1$-casein $(\%)$ & $10.68^{\mathrm{a}} \pm 1.13$ & $13.82^{\mathrm{ab}} \pm 1.13$ & $14.33^{b} \pm 1.12$ & * \\
\hline$\beta$-casein (\%) & $53.29 \pm 2.32$ & $50.50 \pm 2.31$ & $48.22 \pm 2.32$ & NS \\
\hline y-casein (\%) & $8.51^{a} \pm 1.64$ & $14.22^{\mathrm{b}} \pm 1.63$ & $18.14^{\mathrm{b}} \pm 1.64$ & $* *$ \\
\hline WSN \%TN & $17.25^{\mathrm{a}} \pm 3.04$ & $23.86^{\mathrm{ab}} \pm 3.03$ & $29.25^{b} \pm 3.03$ & * \\
\hline TCA-SN \%TN & $9.49^{\mathrm{a}} \pm 1.42$ & $14.45^{\mathrm{b}} \pm 1.41$ & $17.93^{b} \pm 1.42$ & $* *$ \\
\hline
\end{tabular}

Means within a row marked with different letter differ significantly, ${ }^{*} \mathrm{P}<0.05,{ }^{* *} \mathrm{P}<0.01$, NS = non significant,

WSN \% TN = water-soluble nitrogen fraction in the total nitrogen, TCA \% TN $=12 \%$-trichloroacetic acid soluble nitrogen fraction in the total nitrogen.

Results of this research showed that the extent of secondary proteolysis, determined by both TCASN \%TN $(\mathrm{P}<0.01)$ and WSN \%TN $(\mathrm{P}<0.05)$ significantly increased in cheese during ripening (Table 2). A similar trend in TCA-SN \%TN and WSN \%TN contents throughout the ripening period were reported by Tudor Kalit et al. (2014) and Şengül et al. (2014). However, comparing the results obtained by the latter authors, we found considerably higher values for these parameters at each stage of cheese ripening. The higher values of WSN \%TN in this research could be also attributed to the higher retention of residual rennet in the curd. According to Farkye (1995), residual rennet contributed more to the evolution of WSN \%TN in comparison to plasmin. Residual rennet has ability to produce mainly large-sized peptides (Desmazeaud et al., 1977) but it shows very limited ability to release free amino acid during ripening of cheese (O'Keeffe et al., 1976). As already mentioned, $1.1 \mathrm{~kg}$ of $\mathrm{NaCl}$ was added to $100 \mathrm{~L}$ of milk prior to renneting. Similarly, Bansal et al. (2007) reported that both, casein micelles and chymosin molecules, were negatively charged and repel each other. According to the authors, addition of $\mathrm{NaCl}$ increased ionic strength in milk leading to decrease in the zeta-potential and less negatively charged surfaces of casein micelles. As surfaces of casein micelles become less neg- 
atively charged, increased interactions between them and chymosin molecules consequently increased the initial retention of chymosin in a curd (Bansal et al., 2007). Rennet is responsible for the production of WSN \%TN and in much lower extent for the production of TCA-SN \%TN (Bansal et. al., 2010). On contrary, bacterial enzymes make a substantial contribution to a production of small-sized peptides, amino acids, ammonia, and other minor compounds that are soluble in $12 \%$ trichloroacetic acid (Desmazeaud et al., 1977; Addeo et al., 1992). Initially, TCA-SN \%TN value was $9.49 \%$ (Table 2) which was 3.5-fold higher than that reported by Tudor Kalit et al. (2014), probably due to a higher content of moisture in cheese during ripening and different autochthonous microorganism species that result with different proteinase and peptidase activities.

\section{Texture}

The changes in textural properties of cheese in a sack during ripening are shown in Figures 1 and 2. Correlation coefficients between proteolysis and textural characteristics of cheese during ripening are shown in Table 3. The results showed that hardness, cohesiveness and springiness significantly $(\mathrm{P}<0.05)$ decreased during ripening. Oluk et al. (2014) reported that springiness showed the same pattern as in this study but opposite results for hardness and cohesiveness. These authors concluded that Tulum cheese became harder and more cohesive during the ripening period which was most probably related to it's compact structure and moisture loss.

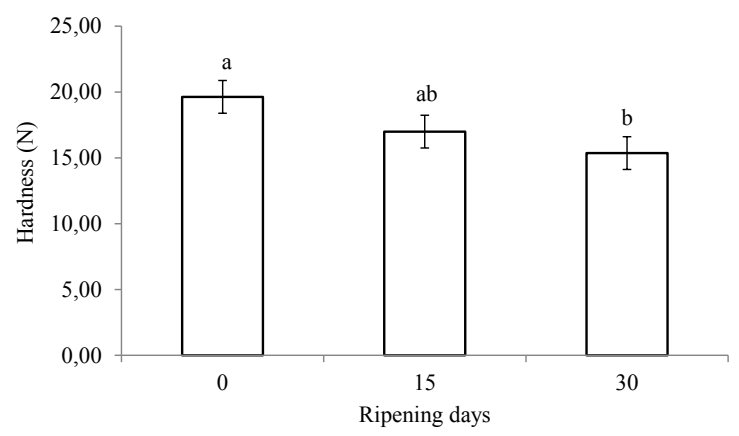

Means within a row marked with different letter differ significantly $(\mathrm{P}<0.05)$.

FIGURE 1. Changes in hardness during ripening of cheese in a sack, $\mathrm{n}=10$ (means \pm standard error)

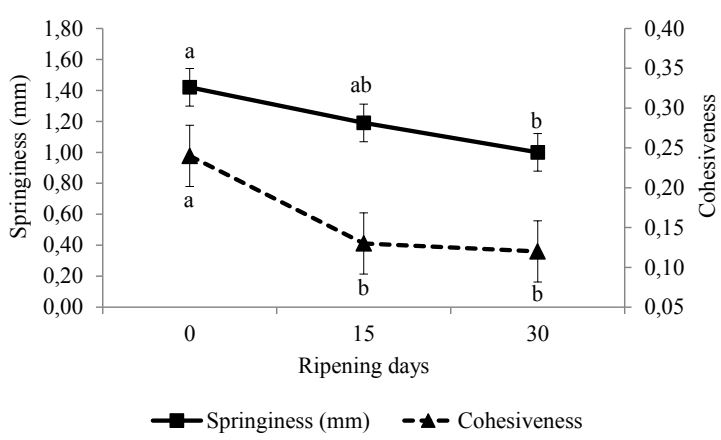

Means within a row marked with different letter differ significantly $(\mathrm{P}<0.05)$

FIGURE 2. Changes in cohesiveness and springiness during ripening of cheese in a sack, $\mathrm{n}=10$ (means \pm standard error)

According to the results of this study (Table 2 and 3) as well as the previous ones (Bertola et al., 1991; Irudayaraj et al., 1999; Lane et al., 1997), extensive proteolysis was the primary cause of decreasing in these texture parameters during ripening. It is well known that extensive proteolysis reduced the number of inter and intra molecular bonds within paracasein network (Lucey et al., 2003). On the other hand, large peptides liberated by hydrolysis of peptide bonds became a part of serum phase and they were not able to contribute to the structure and texture of cheese (Ong et al., 2017). However, considering that the extensive proteolysis reduced the number of bonds, it could be expected that both cohesiveness and springiness decreased with its reduction (Tunick et al., 1993; Lane et al., 1997). The decrease in values of textural properties could also be attributed to the slower moisture loss during ripening (Table 1) since many authors pointed out the importance of moisture contribution to cheese texture (Prentice et al. 1994). According to Gunasekaran and Ak (2003), moisture occupies spaces between fat and protein in cheese structure and due to its low viscosity acts as a good lubricant. The amount of fat entrapped within the paracasein matrix and its physical state have a large impact on textural properties of cheese. As indicated above, measurement of texture was performed at $25{ }^{\circ} \mathrm{C}$ which meant that most of the fat was liquid and also provided a lubricating effect in cheese (Guinee and Law, 2002; Gunasekaran and Ak, 2003). Hence, the following facts supported the conclusion that moisture along with the fat played an important role 
in reducing cheese hardness. Therefore, it could be expected that cheese in a sack became softer, less cohesive and less springy during ripening (Table 3).

TABLE 3. Correlation coefficients between composition, proteolysis and textural characteristics of Sir iz mišine

\begin{tabular}{|l|l|l|l|}
\hline Parameter & Hardness & Cohesiveness & Springiness \\
\hline Moisture & 0.31 & 0.34 & 0.29 \\
\hline MNFS & 0.08 & $0.42^{*}$ & 0.12 \\
\hline$\gamma$-casein & -0.35 & -0.37 & -0.46 \\
\hline$\beta$-casein & -0.27 & 0.30 & 0.04 \\
\hline$a_{\text {s1 }}$-casein & -0.02 & 0.18 & $0.52^{* *}$ \\
\hline $\begin{array}{l}\mathrm{a}_{\text {s1 }}-\mathrm{I}- \\
\text { casein }\end{array}$ & -0.22 & -0.28 & $-0.68^{* *}$ \\
\hline WSN \%TN & $-0.40^{*}$ & $-0.64^{* *}$ & 0.11 \\
\hline $\begin{array}{l}\text { TCA-SN } \\
\text { \%TN }\end{array}$ & $-0.51^{* *}$ & $-0.52^{* *}$ & $-0.39^{* *}$ \\
\hline
\end{tabular}

MNFS=moisture in non-fat substance, WSN \% TN = watersoluble nitrogen fraction in total nitrogen,

TCA \%TN= $12 \%$-trichloroacetic acid soluble nitrogen fraction in total nitrogen, ${ }^{*} \mathrm{P}<0.05,{ }^{*} \mathrm{P}<0.01$

The correlation coefficients between chemical and biochemical parameters and texture of cheese presented in Table 3 indicated that the textural weakening effect of caseinolysis predominated over strengthening effect of moisture loss in texture development of cheese in a sack during ripening. This is not in agreement with previous studies on ewe's milk cheeses that ripen in a natural rind (Gaya et al., 1990; Picon et al., 2010) which indicates the specific role of skin sack on the textural and proteolytic changes during ripening of cheese.
In addition, results of this study showed that both TCA-SN \%TN and WSN \%TN could be good indicators of relationship between proteolysis and textural properties of Sir iz mišine during the early ripening (Table 3).

\section{Conclusion}

The physico-chemical composition, proteolytic and textural characteristics of Croatian cheese in a lamb skin sack (Sir iz mišine) were affected by the ripening time. Sir iz mišine was subjected to a very intense proteolysis, since there was an increase in the content of all proteolytic indicators throughout ripening. Regarding the textural properties, a cheese in a sack became softer, less cohesive and less springy during ripening period. Results of this research showed that weakening effect of caseinolysis predominated over strengthening effect of moisture loss in texture development of a cheese, which could be attributed to the specific conditions during ripening in the animal skin sack. Proteolysis as important biochemical process should be controlled due to its role in achieving desirable sensorial quality of cheese, which is consisted of appearance, flavour, colour, odour and texture.

\section{Acknowledgements}

This work was supported by grant from the Split-Dalmatia County, Agriculture Development Programme - A101007, Agreement Number 402$01 / 11-01 / 321$. The authors would like to thank to Jagoda Vuletić with special thanks to her family for hospitality and support.

\section{Utjecaj kemijskog sastava i proteolize na teksturne karakteristike sira iz mišine}

Sažetak

Cilj ovog istraživanja bio je utvrditi promjene fizikalno-kemijskih, proteolitičkih i teksturnih značajki sira iz mišine tijekom zrenja od 30 dana. Prema tradicionalnom postupku proizvodnje, proizvedeno je 10 šarži sira. Udio suhe tvari, masti, proteina $(P<0.05)$ i soli $(P<0.01)$ se značajno povećavao tijekom zrenja sira. Rezultati istraživanja su pokazali bržu razgradnju $a_{s 1}$ kazeina u odnosu na $\beta$-kazein. Opsežna i značajna $(P<0.05)$ razgradnja $a_{s 1}$ kazeina je popraćena značajnim $(P<0.05)$ povećanjem udjela 
$a_{s 1}$-I-kazeina. lako je utvrđena umjerena razgradnja $\beta$-kazeina u siru, statistički značajne razlike nisu utvrđene. Međutim, udio $\gamma$-kazeina se značajno $(P<0,01)$ povećavao tijekom zrenja sira. Kao posljedica intenzivne proteolize, došlo je do značajnog povećanja udjela TCA-SN $(P<0,01)$ i WSN $(P<0,05)$. Rezultati su pokazali značajno $(P<0,05)$ smanjenje čvrstoće, kohezivnosti i elastičnosti tijekom zrenja sira odnosno s progresom proteolize. Učinak omekšavanja sira kao posljedica kazeinolize nadvladao je učinak učvršćivanja sira kao posljedica gubitka vlage, što se može pripisati specifičnim uvjetima u mišini tijekom zrenja sira.

\section{Ključne riječi: sir iz mišine, proteoliza, tekstura, zrenje sira.}

\section{References}

1. Addeo, F., Chianese, L., Salzano, A., Sacchi, R., Cappuccio, U., Ferranti, P., Malorni, A. (1992): Characterization of the $12 \%$ trichloroacetic acid insoluble oligopeptides of Parmigiano-Reggiano cheese. Journal of Dairy Research 59, 401-411. https://doi.org/10.1017/S0022029900030673

2. AOAC (1995): Chloride (Total) in Cheese, Volhard Method AOAC Official Method 935.43. Washington, DC: Association of Official Analytical Chemists.

3. Ardö, Y., McSweeney, P.L.H., Magboul, A.A.A., Upadhyay, V.K., Fox, P.F. (2017): Biochemistry of cheese ripening: Proteolysis. In: Cheese Chemistry, Physics \& Microbiology, Vol. 1, eds. McSweeney, P.L.H., Fox, P.F., Cotter, P.D., Everett, D.W., Elsevier academic press, 445-482. https://doi.org/10.1016/B978-0-12-417012-4.00018-1

4. Bansal, N., Fox, P.F., McSweeney, P.L.H. (2007): Factors Affecting the Retention of Rennet in Cheese Curd. Journal of Agricultural and Food Chemistry 55, 9219-9225. https://doi.org/10.1021/jf071105p

5. Bansal, N., Piraino, P., McSweeney, P. L. H. (2010): Determination of proteolysis in cheese. In: Handbook of Dairy Food Analysis, eds. Nollet, L.M.L., Toldrá, F., CRC Press, Taylor \& Francis Group, 405-426.

6. Bertola, N.C., Bevilacqua, A.E., Zaritzky, N.E. (1991): Changes in rheological and viscoelastic properties and protein breakdown during the ripening of Port Salut Argentino cheese. International Journal of Food Science and Technology 26, 467-478.

https://doi.org/10.1111/j.1365-2621.1991.tb01991.x

7. Bijeljac, S., Sarić, Z. (2005): Autohtoni mliječni proizvodi sa osnovama sirarstva. Poljoprivredni Fakultet Univerziteta u Sarajevu, Sarajevo, Bosna i Hercegovina.

8. Celik, O.F., Tarakci, Z. (2017): The effects of starter cultures on chemical, biochemical and sensory properties of low-fat Tulum cheeses during ripening. International Journal of Dairy Technology 70, 1-9. https://doi.org/10.1111/1471-0307.12377

9. Desmazeaud, M.J., Gripon, J.C. (1977): General mechanism of protein breakdown during cheese ripening. Milchwissenschaft 32, 731-734.

10. Farkye, N., Fox, P.F. (1999): Contribution of rennet and starter proteases to proteolysis in Cheddar cheese. Journal of Dairy Research 59, 209-216. https://doi.org/10.1017/S0022029900030454
11. Farkye, N.Y. (1995): Contribution of milk-clotting enzymes and plasmin to cheese ripening. In: Chemistry of StructureFunction Relationships in Cheese, eds. Malin, E.L. and Tunick, M.H., Plenum Press, New York, 195-207. https://doi.org/10.1007/978-1-4615-1913-3_11

12. Fenelon, M.A., Guinee, T.P. (1999): The effect of milk fat on Cheddar cheese yield and its prediction, using modifications of the Van Slyke cheese yield formula. Journal of Dairy Science 82, 2287-2299. https://doi.org/10.3168/jds.S0022-0302(99)75477-9

13. Fox, P.F., Guinee, T.P., Cogan, T.M., McSweeney, P.L.H. (2000): Biochemistry of cheese ripening. In: Fundamentals of cheese science, ed. Colilla, J., Aspen Publishers, Gaithersburg, Maryland, SAD, 236-278.

14. Gaya P., Medina M., Rodriguez-Marin M.A., Nuñez M. (1990): Accelerated ripening of ewes' milk Manchego cheese the effect of elevated ripening temperatures. Journal of Dairy Science 73, 26-32. https://doi.org/10.3168/jds.S0022-0302(90)78641-9

15. Guinee, T.P., Law, B.A. (2002): Role of milk fat in hard and semihard cheeses. In: Fats in food technology, ed. Rajah, K.K., Sheffield Academic Press, 275-331.

16. Gunasekaran, S., Ak, M.M. (2003). Cheese rheology and texture. New York, CRC Press.

17. Havranek, J., Kalit, S., Antunac, N., Samaržija, D. (2014): Sirarstvo. Hrvatska mljekarska udruga, Zagreb.

18. Hayaloglu, A.A., Cakmakci, S., Brechany, E.Y., Deegan, K.C., McSweeney, P.L.H. (2007): Microbiology, biochemistry, and volatile composition of Tulum cheese ripened in goat's skin or plastic bags. Journal of Dairy Science 90, 11021121. https://doi.org/10.3168/jds.S0022-0302(07)71597-7

19. HRN EN ISO 5534 (2008). Cheese and processed cheese -Determination of the total solids content. Croatian Standards Institute, Zagreb.

20. HRN ISO 3433 (2009). Cheese - Determination of fat content - Van Gulik method. Croatian Standards Institute, Zagreb.

21. HRN EN ISO 8968-1 (2014). Milk and milk products determination of nitrogen content - Part 1. Croatian Standards Institute, Zagreb.

22. Irudayaraj, J., Chen, M., McMahon, D.J. (1999): Texture development in Cheddar cheese during ripening. Canadian Agricultural Engineering 41, 253-258. 
23. Kalit, S. (2002.): Zrenje sireva. Zbornik predavanja četvrtog savjetovanja uzgajivača ovaca i koza u Republici Hrvatskoj, Varaždinske toplice, 47-56.

24. Kalit, S. (2015): Utjecaj kvalitete mlijeka i tehnoloških postupaka proizvodnje na randman sira, Zbornik predavanja sedamnaestog savjetovanja uzgajivača ovaca i koza u Republici Hrvatskoj, Varaždin, 21-31.

25. Lane, C.N., Fox, P.F., Johnston, D.E., McSweeney, P.L.H. (1997): Contribution of coagulant to proteolysis and textural changes in Cheddar cheese during ripening. International Dairy Journal 7, 453-464. https://doi.org/10.1016/S0958-6946(97)00041-1

26. Lešić, T., Pleadin, J., Krešić, G., Vahčić, N., Markov, K., Vrdoljak, M., Frece, J. (2015): Chemical and fatty acid composition of cow and sheep cheeses in a lamb skin sack. Journal of Food Composition and Analysis, 46, 70-77. https://doi.org/10.1016/j.jfca.2015.11.007

27. Lteif, L., Olabi, A., Kebbe Baghdadi, O., Toufeili, I. (2009): The characterization of the physicochemical and sensory properties of full-fat, reduced-fat, and low-fat ovine and bovine Halloumi. Journal of Dairy Science 92, 4135-4145. https://doi.org/10.3168/jds.2009-2070

28. Lucey, A.J., Johnson, E.M., Horne, S.D. (2003): Invited review: Perspectives on the basis of the reology and texture properties of cheese. Journal of Dairy Science 86, 2725-2743. https://doi.org/10.3168/jds.S0022-0302(03)73869-7

29. Lukač Havranek, J., Hadžiosmanović, M., Samaržija, D., Antunac, N. (2000): Prehrambena svojstva mediteranskih sireva. Mljekarstvo 50, 141-150.

30. Mateo, M.J., Everard, C.D., Fagan, C.C., O'Donnel,I C.P., Castillo, M., Payne, F.A., O'Callaghan, D.J. (2009): Effect of milk fat concentration and gel firmness on syneresis during curd stirring in cheese-making. International Dairy Journal 19, 264-268. https://doi.org/10.1016/j.idairyj.2008.10.014

31. McSweeney, P.L. (2004): Biochemistry of cheese ripening. International Journal of Dairy Technology 57, 127-144. https://doi.org/10.1111/j.1471-0307.2004.00147.x

32. O'Keeffe, R.B., Fox, P.F., Daly, C. (1976): Contribution of rennet and starter proteases to proteolysis in Cheddar cheese. Journal of Dairy Research 43, 97-107. https://doi.org/10.1017/S0022029900015636

33. Oluk, A.C., Güven, M., Hayaloglu, A.A. (2014): Proteolysis texture and microstructure of low-fat Tulum cheese affected by exopolysaccharide-producing cultures during ripening. International Journal of Food Science and Technology 49, 435-443. https://doi.org/10.1111/ijfs.12320

34. Ong, L., Lawrence, R.C., Gilles, J., Creamer, L.K., Crow, V.L., Heap, H.A., Honoré, C.G., Johnston, K.A., Samal, P.K., Powell, I.B., Gras, S.L. (2017): Cheddar Cheese and related drysalted cheese varieties. In: Cheese Chemistry, Physics \& Microbiology, Vol. 1, eds. McSweeney, P.L.H., Fox, P.F., Cotter, P.D., Everett, D.W., Elsevier academic press, 829-863. https://doi.org/10.1016/B978-0-12-417012-4.00033-8

35. Picon, A., Gaya, P., Fernández-García, E., Rivas-Cañedo, A., Ávila, M., Nuñez, M. (2010): Proteolysis, lipolysis, volatile compounds, texture, and flavor of Hispánico cheese made using frozen ewe milk curds pressed for different times. Journal of Dairy Science 93, 2896-2905. https://doi.org/10.3168/jds.2009-3041
36. Pirisi, A., Pinna, G., Addis, M., Piredda, G., Mauriello, R., De Pascale, S., Caira, S., Mamone, G., Ferranti, P., Addeo, F., Chianese, L. (2007): Relationship between the enzymatic composition of lamb rennet paste and proteolytic, lipolytic pattern and texture of PDO Fiore Sardo ovine cheese. International Dairy Journal 17, 143-156. https://doi.org/10.1016/j.idairyj.2006.02.001

37. Prentice, J.H., Langley, K.R., Marshall, R.J. (1994.): Cheese rheology. In: Cheese: Chemistry, Physics and Microbiolog, Vol. 1., ed. Fox, P.F., An Aspen Publication, 299-343.

38. Prieto, B., Franco, I., González Prietow, J., Bernardow, A., Carballo, J. (2002): Compositional and physico-chemical modifications during the manufacture and ripening of León raw cow's milk cheese. Journal of Food Composition and Analysis 15, 725-735. https://doi.org/10.1006/jfca.2002.1055

39. Sánchez-Macías, D., Fresno, M., Moreno-Indias, I., Castro, N., Morales-dela Nuez, A., Álvarez, S. (2010): Physicochemical analysis of full-fat, reduced-fat, and low-fat artisan-style goat cheese. Journal of Dairy Science, 93, 3950-3956. https://doi.org/10.3168/jds.2010-3193

40. Şengül, M., Erkaya, T., Dervişoğlu, M., Aydemir, O., Gül, O. (2014): Compositional, biochemical and textural changes during ripening of Tulum cheese made with different coagulants. International Journal of Dairy Technology 67 , 373-383. https://doi.org/10.1111/1471-0307.12120

41. Sousa, J.M., Ardö, Y., McSweeney, H.L.P. (2001): Advances in the study of proteolysis during cheese ripening. International Dairy Journal, 11, 327-345. https://doi.org/10.1016/S0958-6946(01)00062-0

42. Tudor Kalit, M., Kalit, S., Delaš, I., Kelava, N., Karolyi, D., Kaić, D., Vrdoljak, M., Havranek, J. (2014): Changes in the composition and sensory properties of Croatian cheese in a lamb skin sack (Sir iz mišine) during ripening. International Journal of Dairy Technology 67, 255-264. https://doi.org/10.1111/1471-0307.12117

43. Tunick, M.H., Mackey, K.L., Shieh, J.J., Smith, P.W., Cooke, P., Malin, E.L. (1993): Rheology and microstructure of low-fat Mozzarella cheese. International Dairy Journal 3, 649-662. https://doi.org/10.1016/0958-6946(93)90106-A

44. Yilmaz, G., Ahmet, A., Akin, N. (2005): The effect of microbial lipase on the lipolysis during the ripening of Tulum cheese. Journal of Food Engineering 69, 269-274. https://doi.org/10.1016/j.jfoodeng.2004.08.017

45. Zengin, G., Gun, I., Mutlu, M. M., Ork, N., Seydim, Z., Candas, A., Zengin, A. (2016): Characterization of waste skins used in Tulum cheese production. Proceedings of 6th International Conference on Advanced Materials and Systems, 65-71. https://doi.org/10.24264/icams-2016.IV.15 